\title{
Cognitive Stupidity
}

James F. Welles

East Marion, New York, 11939, USA.

Corresponding Author James F. Welles, East Marion, NewYork, 11939, USA

Received date: February 29, 2020; Accepted date: March 05, 2020; Published date: March 18, 2020.

Citation: James F. Welles (2020) Cognitive Stupidity, 3(1): Doi: 10.31579/2692-9422/008

Copyright: (c) 2020 James F. Welles, This is an open-access article distributed under the terms of The Creative Commons Attribution License, which permits unrestricted use, distribution, and reproduction in any medium, provided the original author and source are credited.

\begin{abstract}
The brain of an infant may be the blank tablet envisaged by Locke, [1] but as it is shaped by both experience and language it develops into the mind of an adult. As the character of the maturing individual becomes defined, the mind shapes experiences decreasingly according to immediate stimuli themselves and increasingly according to linguistic interpretations of and emotional reactions to perceptions. Thus, the environment does not dictatehuman behavior but provides a context for its expression.
\end{abstract}

Keywords: body language, music, environmental stimuli

\section{Introduction}

The basis for interpreting environmental stimuli is the schema-thecognitive program (Ger: Weltanschauung) which acts as a template for perceptual experience and provides expectations and explanations about objects and their relations to and interactions with each other [2] .It is populated by or constructed of memes, [3] which are subjected to selection pressure by the psycho-cultural environment and thus are not necessarily as true as they are gratifying and popular. Just as a reigning intellectual paradigm defines each of our modern sciences (e.g., atoms in chemistry) [4], aschema defines the mental life of an individualby providing an intellectual frame of reference for information, ideas and behavior. Traceable back to Edmound Husserl's phenomenological observation of the mind's tendency to organize experiences, [5] like Piaget's mental structure, [6] it comprises the "Cognitive map" of the individual's reality and determines his 1.) worldview, 2.) self-concept,3.) self-ideal and 4.) ethical convictions.

While providing basic notions about principles of nature and theories about how the world works, the schema both fosters and inhibits further learning. It is particularly good at promoting learningof refinement, whereby established expectations are confirmed and reinforcedandresponses made more subtle. However, learning of novelty is made less probable and more difficult by preset patterns of thought which limit an individual's range of cognitive adjustment. Thus, the schema en- courages self-corrective, fine tuning of itself even in cases in which it remains a maladaptive beha- vioral program.

The learning process can be broken down into two interrelated steps: assimilation and accommodation [7].Assimilation is the perception of stimuli and the incorporation of experience into an existing schema; it is accomplished by assigning the percept of an object or phenomenon to an established cognitive category as defined by the individual's vocabulary[1]. Accommodation is the change or modification of the schema due to the assimilation of new information. Minor adjust- ments, refinements and modifications of the schema are very common and occur with little or no awareness or emotion. The resulting schema is the individual's reorganization of his experience into a system which provides both predictability of events and a sound basic strategy for successful behavior.

\section{References}

1. Locke, J. (1690) An Essay Concerning Human Understanding. Bk. II, Chap. I, Sec. 2. Locke's psychologyprovided thebasis for the American/environmental- ist/learning side of the Nature/ Nurture controversy. The European/genetic/intrinsic side was first broached by Immanuel Kant, who attributed inherent structure to the human mind (leadingto such traits as aggression, curiosityand morality). The Heg- elian synthesis offered here is that language and social values in one's cultural en- vironment structure the mind and make us human/stupid.

2. Hamilton, D. (1979) A cognitive-attributional analysis of stereotyping. In Ad- vances in Experimental Social Psychology edited by L. Berkowitz. Academic Press; New York. Vol. 12, 53-84. Ericsson, K. and Simon, H. 1993. Verbal Reports as Data. MIT Press; Cambridge, MA.

3. Dawkins, R. (1986). The Blind Watchmaker. Longman; London. 158.

4. Kuhn, T (1996). The Structure of Scientific Revolutions. $3^{\text {rd }}$ ed.University of Chicago Press; Chicago, IL. Chap 2.

5. Husserl, E. 1900-1901. Logische Untersuhungen. (Logical Investigations.)

6. Piaget, J. Structurism. (1971)

7. Piaget, J. (1932). The Moral Judgement of the Child. Macmillan; New York. 